\title{
Mathematical Abstraction Abilities of Hight School Students in Term of Cognitive Style
}

\author{
Anna Rachmadyana Harry ${ }^{1}$, Endang Cahya M.A. ${ }^{2}$, Al Jupri. ${ }^{3}$ \\ \{annaharry18@upi.edu1, endangcahya@gmail.com², aljupri@upi.edu³ $\}$ \\ School of Postgraduate, Indonesia University of Education., Dr. Setiabudi St. No 229 Bandung \\ 40154, Indonesia ${ }^{123}$
}

\begin{abstract}
The purpose of the research carried out is to describe the classification of the level of mathematical abstraction ability in the material sequence and series in terms of the cognitive style of the students. The MFFT cognitive style test results group students into 4 cognitive style groups, namely impulsive (I), reflective (R), impulsive and reflective (IR), and not impulsive and not reflective (TITR). Mathematical abstraction abilities are divided into 4 levels, level 1 perceptual abstraction, level 2 internalization, level 3 interiorization, and level 4 second level of interiorization. Linkages were found between the level of mathematical abstraction and the cognitive style of IR. Several types of errors are found when students solve mathematical abstraction questions including the category of error CE (Comprehension Error), TE (Transformation Error), PSE (Process Skill Error), and EE (Encoding Error).
\end{abstract}

Keywords: Mathematical Abstraction, Sequences and Series, Cognitive Style, Student Mistakes, Newman's Theory

\section{Introduction}

Mathematics learning is certainly independent of the process of forming a special concept experienced by students. The concepts obtained by students are related to experiences that have been formed before, so the formation of new concepts related to experiences or schemes that have been owned by students is called the mathematical abstraction process. The ability of mathematical abstraction is an internal factor in learning that still escapes the attention of educators[1]. The internal factor in question is a factor that supports learning originating from the students themselves.

The research conducted in [2] detail the other internal factors that influence mathematics learning including intelligence, attention, interest, talent, maturity, and readiness. Intelligence is one of the urgencies of this research. The results of the abstraction process are new concepts formed. Abstraction occurs when someone realizes the same characteristics of an object based on the experiences that have been passed [3]. From these experiences, similarities will be obtained which serve as the basis for classifying. In line with the process, it is clear that abstraction is very dependent on previous experience that happened to someone.

Some relevant studies regarding mathematical abstraction have compiled indicators of this ability. This study adopts mathematical abstraction indicators that have been modified by [4]. The indicators of mathematical abstraction ability are shown in Table 1 below. 
Table 1. Level and mathematics abstraction skills indicator.

\begin{tabular}{ll}
\hline Abstraction Level & \multicolumn{1}{c}{ Indicator } \\
\hline $\begin{array}{l}\text { Perceptual } \\
\text { Abstraction }\end{array}$ & $\begin{array}{l}\text { a. Get to know the properties of mathematical objects based on the use } \\
\text { of physical objects. } \\
\text { b. Recognize previous experiences related to the problem at hand } \\
\text { a. Represent the results of thought in the form of mathematical } \\
\text { symbols, words or diagrams. } \\
\text { b. Able to solve / manipulate problems. } \\
\text { a. Organize (collect, compile, develop and coordinate) concepts into } \\
\text { new understanding or new knowledge. }\end{array}$ \\
$\begin{array}{ll}\text { Interiorization } \\
\text { Interionization }\end{array}$ & $\begin{array}{l}\text { a. Generalize new knowledge in different contexts. } \\
\end{array}$
\end{tabular}

Furthermore, students' cognitive activities in learning will show their cognitive style. Cognitive style is a way of receiving or managing students' attitudes in receiving information, as well as habits associated with learning [5]. Based on these definitions it can be concluded that cognitive style influences student achievement in learning. This achievement certainly begins with the concept formation process that occurs in learning activities.

Cognitive style is a heuristic used by someone to process information in the surrounding environment [6]. According to [7] cognitive style is a different way to see, recognize, and organize information. Every individual has a certain preferred way of processing and organizing information in response to environmental stimuli. [8-9] focused impulsive-reflective cognitive style in his research. Impulsive-reflective cognitive style is defined as a form of cognitive system that combines time in decision making and accuracy in problem solving.

[8-9] mentions the dimensions of impulsive-reflective cognitive style including the speed with which students make decisions when facing a problem with high decision uncertainty. Reflective cognitive style students have the characteristics of being slow in solving problems but are careful, so answers tend to be correct. Students with impulsive cognitive style have the characteristic of quickly solving problems but are not careful enough so that answers tend to be wrong.

The study and analysis of research carried out focuses on the results of students' answers in completing mathematical abstraction ability test questions. Most students who take mathematics lessons find it difficult to understand. Difficulties experienced by students cause mistakes made when students solve math problems. In this case the mistakes made by students are examined based on their cognitive style.

When students face problems in solving problems, then the student has passed a series of problem solving steps which include five steps of solving: a) Reading errors (Reading errors); b) Error in understanding the problem (Comprehension error); c) Error Transforming (Transformation error); d) Errors in process skills (Process skill errors); and e) Error in writing the final answer (Encoding error).

\section{Methodology}

This research is a descriptive study using a qualitative approach. The research carried out aims to determine the classification of the level of mathematical abstraction of high school students, the relationship between the level of mathematical abstraction with the cognitive style 
of students and analyze the errors experienced by students in completing mathematical ability abstraction test questions on material lines and series in terms of cognitive style.

The subject of this study was a class XI student of one of the state high schools in Bandung. The selection of research subjects was done by reducing 31 students who took the cognitive style test to get 7 students with different levels of abstraction ability [10]. The research carried out is a qualitative study, where the researcher is the main instrument in the study. The tasks of researchers include as planners, selecting informants, as executors of data collection, interpreting data, drawing temporary conclusions and analyzing data that occurs in the field. The results obtained will be presented and explained descriptively based on data obtained in the field. This is in accordance with the characteristics of qualitative research which is an activity of understanding phenomena that occur with explanations in the form of descriptions and does not prioritize generalizations based on the results obtained in numerical form.

\section{Result and Discussion}

Based on the analysis of cognitive style test results showed 27 students have Impulsive cognitive style or $93 \%$ of all students who take the cognitive style test and 2 students have Reflective cognitive style. Furthermore, there are 1 students who are included in the category of Impulsive and Reflective cognitive styles and 2 students are not included in both.

Next, a mathematical abstraction ability test is carried out. The questions are arranged based on indicators according to [4]. After obtaining cognitive style data and answer sheets of students' mathematical abstraction ability tests, interviews were carried out by taking samples from all students who took the cognitive style test, with details of 1 Impulsive student, 1 Reflective student, 1 Impulsive and Reflective student, and 1 non-Impulsive and not student Reflective.

After a more in-depth analysis of 4 students with different cognitive styles, the data obtained was not enough to describe the answers to the problem formulation. Thus, further observation data was collected by adding interview participants to the details of 1 Impulsive student, 1 Reflective student, and 1 student not Impulsive and not Reflective. The total number of interview participants is 7 people. Considerations taken by selecting 7 students to carry out the interview are the record of time, the number of mistakes made, the ability to communicate opinions both verbally or in writing, and relatively similar mathematical abilities.

Below will be shown the results of the mathematical abstraction ability test answers from several students with different cognitive styles. Figures 1. Displays the answers of Impulsive students working on Level 1 Perceptual Abstraction questions. 


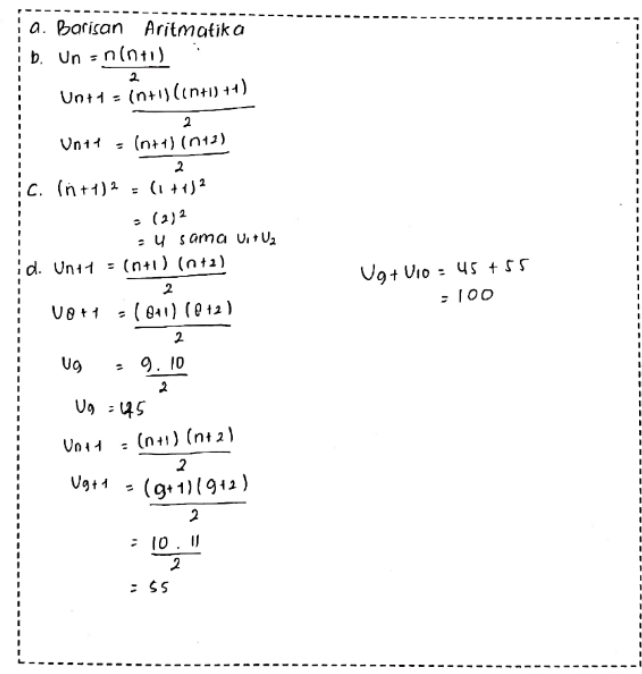

Fig. 1. Level 1 Answers Impulsive Students.

Figure above is the result of answers from impulsive students. Impulsive cognitive style is characterized by students being quick in answering and answers tend to be wrong. Point a measures the level 1 indicator, which is recognizing the nature of an object that is seen. Students can answer that the sequence in problem 1 is an arithmetic sequence. Next point b displays a new object in the form of a formula from the nth term of an arithmetic sequence, point $b$ is the first step to remind students of the experience in learning algebra, which determines the formula by substituting $(n+1)$ on the existing $U n$ formula. The formula $U_{(n+1)}$ will then be used in point c. It turns out that student answer on point $\mathrm{c}$ has not fullfilled the indicator on level 1 , which is student solved the problem based on their experience. The answer on point $\mathrm{c}$ shows that studens did not understand question that being asked. Therefore on level 1 impulsive students' still on transition proccess. Figures 2. Displays students' reflective answers in working on Level 2 Internalization questions.

$$
\begin{aligned}
& a \cdot U_{1}, U_{2}, U_{6}=b \text { ocison geonefli } \\
& b . U_{1}=a \quad U_{2}=a+b \quad U_{3}=a+2 b \\
& a+a+b+a+5 b=42 \quad a+a r+a r^{2}=42 \\
& 3 a+6 b=42 \quad \frac{U_{1}}{U_{2}}=\frac{U_{3}}{U_{2}} \rightarrow \frac{a}{a r}=\frac{a r^{2}}{a r} \\
& a=0 . r^{2}
\end{aligned}
$$

Fig. 2. Level 2 Answers Reflective Students.

In addition to the concept of comparison that is less mastered, Reflective students are also mistaken in choosing the concept of sequence used to calculate differences. Obviously the questions asked differ from arithmetic sequences, but students use geometric sequence formulas. The mistake in choosing the formula caused students to be unable to continue the calculation, so they did not find the difference asked. As a result Reflective students cannot answer questions points $\mathrm{c}$ and d. By seeing students' answers in the picture above Reflective students are only able to write mathematical models of the problem, it shows that reflective 
students are included in level 2 in the transition. Figures 3. Displays the answers of Impulsive and Reflective students in working on Level 3 Interiorization questions.

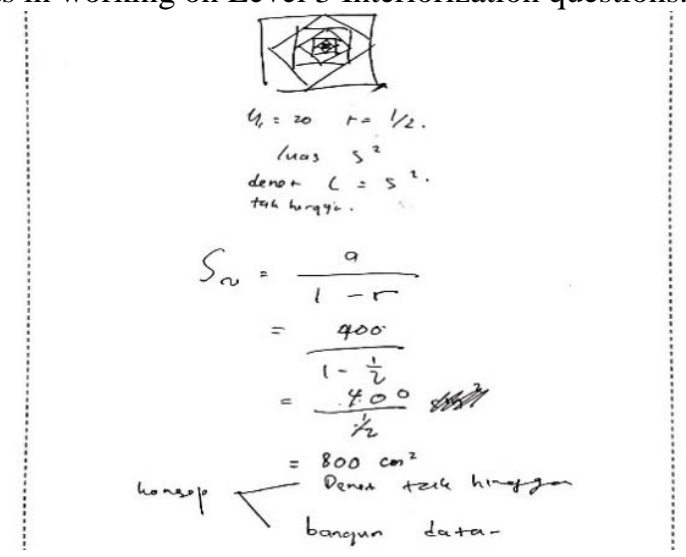

Fig. 3. Level 3 Answers Impulsive and Reflective Students.

IR students can describe a square shape formed. By paying attention to the explanation that the vertex of the second square is at the midpoint of the first square, students can draw the conclusion that the area of the second square is $\frac{1}{2}$ of the area of the first square, as well as the next square. After that students can also know that $\frac{1}{2}$ is the ratio formed from geometric rows arranged by the area of the whole square. Students use the concept of infinite geometry series and succeed in determining the total area of the square that is formed. That means students have reached level 3 interiorization indicators completely. Figures 4. Displaying the answers that are not impulsive and not reflective in working on Level 4 Second Level of Interiorization problems.

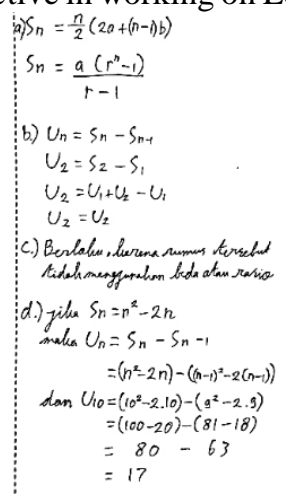

Fig. 4. Level 4 Answers Students Are Not Impulsive and Not Reflective.

Students who are not impulsive and not reflective can write the formula for the number of arithmetic and geometric sequences at point a. Furthermore, point $b$ students can prove the formula U_n applies to arithmetic sequences, students don't prove to geometry sequences. For point c, students express the formula U_n applies to any sequence. Based on the students' answers, students who are not impulsive and not reflective are at level 4 of the transition. Based on the results of analysis and student interviews, obtained data will be presented in the following Table 2 and Table 3. 
Table. 2. $\mathrm{Cl}$ Level Abstraction (Level 1 - 4) lasers Reviewed from Cognitive Style $\mathbf{N}=\mathbf{7}$.

\begin{tabular}{lllll}
\hline $\begin{array}{c}\text { Cognitive } \\
\text { Style }\end{array}$ & & \multicolumn{3}{c}{ Abstraction Level } \\
\\
\hline I & Transition & Complete (1) & Transition & Transition \\
$\mathbf{R}$ & Complete (1) & Transition & Complete (1) & Transition \\
IR & Complete (1) & Complete (1) & Complete (1) & Complete (1) \\
TITR & Complete (1) & Transition & Transition & Transition \\
\hline
\end{tabular}

Table 3. Types of Student Mistakes in Completing Mathematical Abstraction Ability Tests.

\begin{tabular}{ccccc}
\hline $\begin{array}{c}\text { Soal } \\
\text { Level }\end{array}$ & SL 1 & SL2 & SL3 & SL 4 \\
\hline \multirow{2}{*}{ SI } & $\boldsymbol{x}$ & $\boldsymbol{x}$ & CE & TE \\
& & & TE & PSE \\
SR & TE & TE & CE & TE \\
& EE & PSE & TE & EE \\
SIR & CE & TE & $\boldsymbol{x}$ & EE \\
& & EE & & \\
STITR & $\boldsymbol{x}$ & PSE & $\boldsymbol{x}$ & EE \\
& & EE & & \\
\hline
\end{tabular}

Information:

$\begin{array}{ll}\text { SL1 - SL } 4 & \text { : Questions Level } 1-\text { Questions Level } 4 \\ \text { SI } & \text { : Impulsive Students } \\ \text { SR } & \text { : Reflective Students } \\ \text { SIR } & \text { : Impulsive and Reflective Students } \\ \text { STITR } & \text { : Students Are Not Impulsive and Not Reflective } \\ \text { CE } & \text { : Comprehension Error } \\ \text { TE } & \text { : Transformation Error } \\ \text { PSE } & \text { : Process Skill Error } \\ \text { EE } & \text { : Econding Error }\end{array}$

\section{Conclusion}

Level 1 perceptual abstraction (the ability to recognize physical objects and recognize previous experiences) can be achieved by impulsive students (I) in transition, and all indicators are fully fulfilled by reflective students (R), impulsive and reflective students (IR), and nonreflective students and not implantive (TITR). Level 2 internalization (representing thoughts in 
the form of symbols and manipulating problems) is achieved in full by student I, and IR students with correct answers include both indicators at this level. Then R students and TITR students are in transition because they can only meet one indicator of the internalization level.

Level 3 interiorization (reorganizing concepts into new understanding or new knowledge) can be completely fulfilled by R students and IR students. Student I and TITR students are in transition because they cannot describe and utilize drawing sketches according to the descriptions in the questions. Level 4 second level of interiorization (generalizing new knowledge in different contexts) is achieved completely by IR students. Students with other cognitive styles namely students I, students R, and TITR students are still in a transition period.

The association was found to occur between the level of mathematical abstraction with impulsive and reflective cognitive styles. Furthermore, some errors found were CE (Comprehension Error), TE (Transformation Error), PSE (Process Skill Error), and EE (Econding Error). This caused students to not be able to reach several levels of mathematical abstraction.

Acknowledgements. The researcher would like to thank profusely to SMA Negeri 1 Bandung for supporting this study.

\section{References}

[1] Warsyidah, A. A., and Arsyad, M.: Pengaruh pendekatan induktif terhadap kemampuan berpikir abstrak dan penguasaan konsep fisika peserta didik kelas VII SMP Negeri 5 Bulukumba. Jurnal Sains dan Pendidikan Fisika, Vol. 12, No. 2, pp. 146-154 (2016)

[2] Fadilah dan Hasby.: Analisis faktor internal yang mempengaruhi hasil studi mahasiswa pendidikan Matematika Universitas Samudra. Prosiding Seminar Nasional MIPA III ISBN 978-602-50939-0-6, Indonesia (2017)

[3] Skemp, R.R.: Psychology Of Learning Mathematics. Routledge Taylor \& Francis Group, US (1987)

[4] Fitriani, N.: Proses abstraksi matematis siswa SMP pada konsep bangun ruang sisi lengkung melalui pendekatan realistic Mathematics Education dengan Model Van Hiele. Ringkasan Disertasi Universitas Pendidikan Indonesia: Unpublished (2018)

[5] Masriyah and Hanifah, U.: Number sense siswa SMP ditinjau dari gaya kognitif. Prosiding Seminar Nasional Pendidikan Matematika ISBN 978-602-449-023-2 (2016)

[6] Kozhevnikov, M.: Cognitive styles in the context of modern psychology: Toward an integrated framework of cognitive style. Psychological Bulletin,Vol. 133, No. 3, pp. 464-481 (2007)

[7] Woolfolk, A.E. (1993). Educational Psychology. London: Allyn and Bacon.

[8] Kagan, J.: Matching Familiar Figure Test. Harvard University, US (1965)

[9] Kagan, J.: Reflection-Impulsivity and reading ability in primary grade children. Child Development, Vol. 36, No. 3, pp. 609-628 (1965)

[10] Creswell, J.W.: Research design pendekatan kualitatif, kuantitatif, dan mixed 3rd Edition. Pustaka Pelajar, Indonesia (2014) 